\title{
The Four Aristotelian Discourses in Medicine: Educational Tools for Physicians
}

\author{
Os Quatro Discursos Aristotélicos na Medicina: Ferramentas Educacionais para Médicos
}

\author{
Hélio Angotti-Neto, Andreia Bosi, Angela Regina Binda da Silva de Jesus \\ Centro Universitário do Espírito Santo - UNESC, Brasil \\ Email:helioangotti@gmail.com
}

Support/ Apoio: FAPES (Fund to Support Research at Espirito Santo / Fundo de Amparo à Pesquisa do Espírito Santo).

\begin{abstract}
The four Aristotelian discourses (Poetic, Rhetoric, Dialectic and Logic) encompass all human verbal communication, and their study in Medical Humanities is an important instrument for medical practice and education. The discourses differ according to their intention, form, credibility and precision, and they can be studied to develop several aspects, such as understanding the patient, empathy, personal development and communication skills. Their study can also stimulate clinical and philosophical thought in general. The study of Poetic includes Narrative Medicine, literature, cultural studies, case reports and arts. Rhetoric includes verbal and non-verbal communication for the purposes of convincing and instructing other people. Dialectic includes clinical investigation thought and research. Logic includes scientific discourse, discursive analysis and education. Aristotelian works remain valuable instruments to develop a complete physician.
\end{abstract}

Keywords: Medical Philosophy, Medical Education, Narrative Medicine, Logic, Clinical Reasoning.

\section{RESUMO}

Os quatro discursos aristotélicos (Poética, Retórica, Dialética e Lógica) compreendem toda a comunicação verbal humana e seu estudo, nas Humanidades Médicas, é um instrumento importante para a educação e a prática médica. Os discursos diferem conforme a sua intenção, forma, credibilidade e precisão e podem ser estudados para desenvolver diversos aspectos como a compreensão do paciente, a empatia, o desenvolvimento pessoal e a capacidade comunicativa. O respetivo estudo também pode estimular o raciocínio clínico e filosófico em geral. O estudo da poética inclui a Medicina Narrativa, literatura, estudos culturais, casos clínicos e artes. A Retórica inclui comunicação verbal e não verbal com o propósito de instruir e convencer o próximo. A Dialética inclui o raciocínio clínico e a pesquisa. A Lógica inclui o discurso cientifico, a análise discursiva e atividades pedagógicas. As obras aristotélicas permanecem como preciosos instrumentos para desenvolver um médico completo.

Palavras-Chaves: Filosofia da Medicina, Educação Médica, Medicina Narrativa, Lógica, Raciocínio Clínico. 


\section{Introduction}

How can one shape a complete physician, able to gather a humanist attitude with the best qualities of a professional active inside a Flexnerian and technological context, and inherited of a positivist world view and formation?

Medicine happens, in essence, within the physicianpatient relationship, both acting as subjects and objects, simultaneously. Both are linked by a given reality perceived by their senses and by their emphatic ability. Such reality is also explained and transmitted by discursive skills of those involved in the act of medicine. Therefore, we can affirm that medicine is essentially interpersonal, radically realist ${ }^{1}$, sensible, discursive, emphatic, inevitably moral and ideally benevolent. Edmund D. Pellegrino ${ }^{2}$ defines the essence of medicine in a teleological form, stating that the objective of medicine can only be found in the clinical and therapeutic encounter among physician and patient.

The physician stands in the intersection described by Edmund Pellegrino as "the most scientific of the humanities, and the most humane of sciences"3 and, therefore, the physician cannot deny the necessity of an integral search encompassing many types of knowledge. James Marcum, in his book "An Introductory Philosophy of Medicine"4, emphasizes the metaphysics, epistemology and ethical aspects that differ from a physician full of technological and scientific knowledge but devoid of an humanistic formation, and a truly humanist physician, formed in an holistic manner, capable of gathering the best of the biomedical legacy with an optimal personal development in humanistic ways and with skills of interpersonal relationship.

This holistic formation within scientific and humanistic aspects also integrates official guidelines for medical education in many countries, as seen, for example, in Brazil (National Educational Council of Brazil, 2013). One of the many forms to search and teach this ideal of complete physician, in an effort to overcome the dichotomy imposed by modernity between humanistic and natural sciences, and to promote interpersonal communication skills, is teaching the four Aristotelian discourses.

Although the four discourses were understood as different entities, apart from each other as completely heterogeneous humanistic disciplines - as can be seen in the alienation of Poetics and Rhetoric from the Organon: containing Dialectics and Logic, and in the academic division in contemporary universities - a recent theory in Brazil renewed the interest in studying the four discourses together as one organic, comprehensive, and complete view of all verbal human communication possible, with important consequences to pedagogical, philosophical and scientific research and thought.

\section{Introdução}

Como formar um médico integral, capaz de reunir uma postura humanista com as melhores características de um profissional atuante dentro do contexto biomédico clássico, herdado de uma visão positivista de mundo?

A medicina acontece, em sua essência, com o contato entre o médico e o paciente, ambos como sujeitos e objetos simultaneamente. Médico e paciente são ligados pela realidade percebida, pelos sentidos e pela capacidade empática; realidade que também é explicada e transmitida pelas capacidades discursivas daqueles envolvidos no ato médico. Por isso, nada mais comum do que afirmar que a medicina é essencialmente interpessoal, radicalmente realista ${ }^{1}$, sensível, discursiva, empática, inevitavelmente moral e idealmente benévola. Edmund Pellegrino definiria a essência da medicina de forma teleológica, afirmando ser o encontro e a relação de cura e terapia entre médico e paciente o seu fim $^{2}$.

O médico está na curiosa intersecção descrita por Edmund Pellegrino como a "mais científica das humanidades e a mais humana das ciências" ${ }^{3} \mathrm{e}$, portanto, não pode negar a necessidade de uma formação integral abrangendo amplos tipos de conhecimento.

Em sua "Introdução à Filosofia da Medicina", James A. Marcum $^{4}$ monta uma análise filosófica sobre os aspectos metafísicos, epistemológicos e éticos que diferem entre um médico repleto de novos conhecimentos científicos e tecnológicos, mas carente da esfera extremamente complexa do caráter humano, e o médico verdadeiramente humanista, de formação integral, capaz de unir o melhor do legado biomédico ao melhor da formação pessoal e do convívio com o próximo.

Esta formação integral em aspectos científicos e humanistas também integra as diretrizes oficiais para a educação médica em diversos países, como pode ser visto, por exemplo, no Brasil (Conselho Nacional de Educação do Brasil, 2013).

Uma das formas capazes de colaborar na formação de um médico mais próximo do ideal, buscando vencer a dicotomia imposta pela modernidade entre ciências humanas e ciências naturais e tornando-o mais capacitado a exercer a interface discursiva com seu paciente, é justamente o ensino dos quatro discursos aristotélicos.

Embora classicamente tenham sido separados, ficando o Organon - que contém os discursos Dialético e Lógico - alienado parcialmente da Poética, da Narrativa e da Retórica, uma obra recente renovou o interesse pelo estudo dos discursos como um corpo orgânico e abrangente de toda comunicação humana verbalmente possível. O filósofo brasileiro Olavo Luís Pimentel de Car- 
The Brazilian philosopher Olavo de Carvalho published his work "Aristotle in a New Perspective: Introduction to the Theory of the Four Discourses", in which he reorganized the discursive modalities in an organic way, a possibility previously foreseen by great philosophers like Avicena and Thomas of Aquinas, but relegated to oblivion in academic environments until now. ${ }^{5}$

The unification of the four discourses as ideal types to be learned and developed in educational efforts can generate a broad and efficacious pedagogical methodology for learning humanistic contents, therefore, it can be used to integrate the physician into the society provided with a good body of humanistic knowledge, an adequate set of communication skills to use with the patient, and a mind well trained for an appropriate clinical and scientific reasoning.

Considering the great amount of responsibility and the expected role of the physician in the society, a fact even criticized by some authors like Ivan Illich ${ }^{6}$, and the extremely broad definition of Health used by international agencies like World Health Organization ${ }^{7}$, which is used in many national health programs around the globe and includes almost every aspect of human life, it does not look pretentious to charge the physician with the obligation of an wide, complex and complete humanistic and scientific formation.

This work attempts to clarify the general characteristics of the four Aristotelian discourses, to outline their use in medicine, and to establish methodologies for their teaching and training by physicians interested in Medical Humanities and cultural and personal development.

\section{The Four Aristotelian Discourses}

There are four ideal types of discursive action. Language itself is obviously not divided in four isolated forms, as it shows many mixed aspects, but each communicative elaboration approaches one ideal type more than the others.

\section{Poetics}

Poetics is the broader discourse. Its objective is to cause, or generate, an impression over the listener. It can be a poem, a narrative, a dialogue, sounds inserted into melodies, and practically any form of verbal expression that approaches sensitive experience of reality and tries to transmit it to others.

In History, the height of Poetics can be seen in the oldest civilizations, where society was grounded in oracular revelations, epic poetry and revelations from sacred scriptures and prophets with commandments and parables. Medicine itself used discursive elements from magic or religious origins ${ }^{8}$.

The credibility of Poetics can greatly vary, according to the authority and fidelity of the one who professes it. valho publicou em 1994 o livro intitulado "Aristóteles em Nova Perspectiva: Introdução à Teoria dos Quatro Discursos", onde remontou as modalidades discursivas de forma orgânica, concepção observada anteriormente por grandes filósofos como Avicena e Tomás de Aquino, mas relegada ao esquecimento nos meios acadêmicos até então ${ }^{5}$.

A unificação dos quatro discursos como tipos ideais a serem apreendidos e desenvolvidos no indivíduo pode gerar uma metodologia de ensino ampla e eficaz para inserir o médico de forma crítica em sua sociedade, capacitando-o discursivamente e provendo habilidades de comunicação a serem usadas com o paciente e provendo uma mente treinada para o raciocínio clínico e científico.

Considerando o grau de responsabilidade e atuação do médico sobre a sociedade, ao ponto de ser criticado muitas vezes como invasivo e exagerado ${ }^{6}$, a abrangência da definição de "saúde" envolvendo praticamente todos os aspectos da vida humana ${ }^{7}$, não parece pretensioso exigir do médico uma formação complexa e ampla, incluindo ciências biomédicas e humanidades.

Este trabalho busca resumir rapidamente as características gerais dos quatro discursos, explicitá-los dentro da medicina e estabelecer metodologias para seu treino junto ao médico interessado em Humanidades Médicas e no seu crescimento cultural e pessoal.

\section{Os quatro discursos Aristotélicos}

Existem quatro tipos "ideais" de discurso. Aqui não há dúvida que a linguagem está dividida em quatro tipos isolados de discurso, mas que cada elaboração comunicativa se aproxima de um dos quatro tipos, mostrando muitas vezes características mistas.

\section{Discurso Poético}

O discurso mais amplo é o Poético. Seu objetivo principal é causar, ou construir, uma impressão no ouvinte. Pode ser um poema, uma narrativa, um diálogo escrito, sons inseridos em melodias e praticamente qualquer forma expressiva verbal que se aproxime da experiência sensitiva da realidade e busque transmiti-la ao outro. $\mathrm{Na}$ escala histórica, seu ápice pode ser visto nas civilizações mais antigas, onde a sociedade se fundamentava em revelações oraculares e escrituras sagradas contendo narrativas e parábolas diversas. A própria medicina se utilizava de elementos discursivos de caráter mágico ou religioso ${ }^{8}$.

A credibilidade do discurso poético pode variar muito, de acordo com a autoridade de quem o professa e sua 
Being the most flexible of all discourses, Poetics also has the least control over its effect, as interpretation over its meaning can be very different for each one that hears.

Although it is the most flexible and imprecise of all discourses, it possesses great capacity of persuasion over a large amount of time, for it embraces the cultural aspects of civilization, guides the imagination and, consequently, the background from which all the other discourses arise.

\section{Rhetoric}

Rhetoric is the discourse that leads the listener to a decision, showing something as feasible or desirable. It can be used to generate action or inaction, approbation or reprobation, favorable or unfavorable notion about something or someone, etc.

Rhetoric searches for an immediate response or effect, using poetic formulations of the general culture accepted by the listeners to create a predetermined response. Its credibility is based mostly on the virtues of the orator, and its prudence and benevolence ${ }^{9}$. There are also aspects inherent to the Rhetoric discourse and to the listener. It is more rigid than Poetic discourse, trying to concentrate discursive formulations toward a desired and specific objective, but it maintains less formality than posterior discourses like Dialectic and Logic.

In History, its peak can be seen in the Greek Polis, used by the great public orators like the Athenian Solon and the Roman Cicero. In the Christian era is represented by the apostles and evangelists, using the epistles as the paradigmatic literary genre to exhort and convert pagans to the new faith.

\section{Dialectic}

Dialectic discourse searches for an approximation from truth by the method of hypothesis confrontation derived from different rhetorical formulations. Ideally, in a dialectical debate, no one wants to win or convince the other, but to convince themselves of what is the most probable option, or the option closer to truth and righteousness. Dialectical debate can be also an internal one, when someone searches personal guidance through different opinions and hypotheses. Dialectical debate has more credibility only among those who agree in participating according to its methods, which are much more rigid than those of Rhetoric and Poetic discourses.

In contrast to Rhetoric, there is no victory linked to convincing someone, but there is "victory" when an approximation of truth is perceived, even if it is not what one or both debaters believed in the beginning of the discourse. confiabilidade. Por ser o menos rígido dos discursos, o poético também é aquele que menos controlo tem sobre seu efeito, já que a possibilidade de interpretação do que transmite costuma ser muito ampla.

Embora seja o menos formal e rígido de todos, possui grande capacidade de convencimento em longo prazo, mesmo que com pouco controle, pois lida com o aspecto cultural da civilização, norteia o imaginário e, consequentemente, gera o substrato de onde sairão os demais discursos.

\section{Discurso Retórico}

O discurso retórico é aquele que busca levar o seu ouvinte a uma decisão ao mostrar algo como verossímil. Pode ser utilizado para gerar: ação ou inação, aprovação ou reprovação ou uma noção favorável ou desfavorável sobre algo ou alguém. O seu efeito busca um resultado imediato e utiliza as formulações poéticas da cultura para gerar no ouvinte um efeito pré-determinado.

A sua credibilidade se baseia principalmente nas características técnicas do próprio discurso e nas características do bom orador, incluindo a Virtude, a Prudência e a Bondade do mesmo9. Quanto à forma, certamente é mais rígido que o poético, procurando concentrar formulações discursivas orientadas quanto ao objetivo desejado, mas ainda guarda muita liberdade formal quando comparado aos tipos posteriores.

$\mathrm{Na}$ história, o seu ápice inicial ocorreu na pólis grega, nas figuras de grandes oradores e políticos como o ateniense Sólon e o romano Cícero. No Ocidente cristão, é exemplificado pelos apóstolos e evangelistas, por meio do gênero literário epistolar, buscando a exortação e a conversão dos pagãos à nova fé.

\section{Discurso Dialético}

O discurso dialético é aquele que busca uma aproximação da verdade por meio da busca do mais provável no confronto de formulações retóricas. Idealmente, nenhum dos participantes de um debate dialético deseja convencer o outro, mas sim, convencer-se acerca do que é o mais próximo do correto e da verdade. O debate dialético pode ser inclusive interno, quando uma pessoa sozinha confronta diferentes hipóteses e opiniões acerca de algo para sua própria orientação.

Dada sua maior complexidade, o discurso dialético possui maior credibilidade somente entre aqueles que consentem em participar conforme as regras do mesmo e as conhecem, regras estas bem mais rígidas do que as dos discursos poético e retórico.

De forma bem diferente do discurso retórico, não há uma vitória discursiva atrelada ao convencimento de alguém, há uma "vitória" quando pode ser percebida uma 
Dialectical discourse found its peak in the great Medieval "Summas", such as the works of Saint Thomas of Aquinas and Saint Abelard, where conflicting hypotheses regarding each problem were confronted systematically in a great literary construction. This was known verbally as the disputatio.

\section{Logic}

Logic is the most rigid of all discourses, and it has greater credibility, although it also demands practice from the listener to be correctly understood and accepted. Starting from premises known to be true, self-evident or most probable, after a dialectical depuration, the Logic discourse reaches inevitable conclusions according to the formal rules of Logic itself. That is, Logic actually works with indestructible formulations, in an apodictically manner. If the premises are correct, the logical argument is indestructible, and any opposition must be in the premises, not in the discourse itself. To deny a logical discourse is to show that it is fallacious or invalid.

The culmination of Logic in History of the Occident was at the beginning of Modern Era, with Cartesianism and other rationalist philosophical formulations, such as those from Spinoza and Leibniz.

The high degree of formality limits the adequate use of Logic in large scale. And, when compared to other discourses, the use of Logic is very restricted inside society, although many people affirm to be entirely logical in their usual argumentation.

\section{The Four Aristotelian Discourses in Medicine}

\section{Poetic in Medicine}

Poetic is predominantly used in anamnesis, to listen to the stories and narratives from the patients. It can be also seen in Case Reports, although in a technical modulation, for their approach to a sensible reality to describe exactly the state of the patient.

In actuality, Poetic studies inside medicine occur in Semiology and Narrative Medicine, as the student struggles to learn how to tell the patient's story and how to describe signs and symptoms. To emphasize the Poetic and Narrative aspect of this discourse, it is important to note that the physician or the medical student is not trying to convince anyone of anything when they are interviewing the patient or describing his or her clinical state. Rather, they are trying to transmit a concrete reality by a discursive modality.

Poetic is used to populate the imagination with necessary discursive elements to promote a complete clinical and therapeutic reasoning. aproximação da verdade, mesmo que não seja aquela defendida no princípio.

O ápice do discurso dialético pode ser observado na época de formulação das grandes sumas medievais, como a Suma Teológica de Tomás de Aquino, onde formulações contrárias são colocadas para verificação de cada tese proposta, num grande edifício de opiniões que passam pelo crivo formal do método de definir a tese e a antítese e buscar a solução. Oralmente era utilizado no debate escolástico, conhecido como disputatio.

\section{Discurso Lógico}

É o mais rigoroso dos discursos, assim como o de maior credibilidade, embora exija grande treino do ouvinte para que a credibilidade seja viável ou consciente. Partindo de premissas específicas, o formulador do discurso alcança conclusões inevitáveis conforme as regras formais da lógica, isto é, busca atuar no campo da certeza, da formulação discursiva apodítica ou indestrutível.

A época em que a lógica alcançou seu maior grau de credibilidade dentro da sociedade ocidental foi o início da era moderna, com o advento do cartesianismo e das demais formulações filosóficas racionalistas, como as de Leibniz e Spinoza.

$\mathrm{O}$ alto grau de rigor limita sobremaneira o seu uso adequado em larga escala, sendo muito reduzido o número de formulações lógicas que podem ser utilizadas dentro da sociedade quando comparadas às demais formulações discursivas.

\section{Os Quatro Discursos Aristotélicos na Medicina}

\section{Poética na Medicina}

O discurso poético é aquele utilizado predominantemente na anamnese, ao ouvir a história do paciente e suas narrativas. Pode ser observado também nos relatos de casos clínicos que, embora utilizem uma linguagem técnica, buscam se aproximar diretamente da realidade sensível.

Atualmente o estudo da poética dentro da medicina ocorre na Medicina Narrativa e nas técnicas de anamnese e descrição de sinais e sintomas. Não se busca convencer ninguém de nada, busca-se uma aproximação da realidade do paciente e sua transmissão ao médico e aos outros elementos da equipa de saúde. É uma tentativa de equipar o imaginário com os elementos discursivos necessários para o raciocínio clínico e terapêutico.

\section{Retórica na Medicina}

O discurso retórico está presente no ato da prescrição 


\section{Rhetoric in Medicine}

Rhetoric is present in moments like medical prescription, therapeutic planning and bioethical and health policy debates. Different narrative (Poetic) formulations can collide, and discursive formulation is used to propose course of actions, in the physician's perspective, or to inform initial preferences, in the patient's point of view.

It is not coincidence that the good orator characteristics described by Aristotle ${ }^{9}$ can be opposed in a very clear manner to the criteria of medical error as can be seen in the Medical Ethics Code in Brazil ${ }^{10}$. Against the classic triad Ineptitude, Imprudence and Negligence stands the Aristotelian triad Virtue, Prudence and Benevolence.

The necessity and recommendation worldwide to develop good communication practices in medical education is inherent to Medicine itself. Considering this, the physician must be a good orator.

\section{Dialectic in Medicine}

Dialectic is used in scientific research, in the process of Hypothesis confrontation and falsification; in hypothetical-deductive clinical reasoning, strengthening or weakening each clinical hypothesis; and in every moment of the patient-physician encounter that reaches for the most probable ending in a hypothetical decision. ${ }^{11}$ Dialectic is in the field of probability, and it is inherent to Medicine itself, considering the inescapable uncertain and probabilistic aspects of the Medical Art (Gorovitz, MacIntyre, 1976).

\section{Logic in Medicine}

Logic reveals itself in the medical discourse mainly in academic and pedagogic formulations. Teaching medicine or presenting results of scientific research in congresses requires Logic. Arguments must be in order, understanding that the sequence of presentation simulates the logical discourse.

More exigent and studied patients can also demand precise and logical explanations for what is happening with their health, and how it can be improved. To attend such demand is an essential step in recognizing patient autonomy in contemporary medicine.

Logic helps the physician to validate a dialectical formulation with greater certainty, searching for discursive internal coherence and completing the hypotheticaldeductive reasoning, following the classic sequence of major premise, minor premise and conclusion.

\section{Discussion}

The medical act includes the patient-physician encounter and is essentially based upon the communication skills of both sides, especially in the physician's perspective. médica, na tentativa de convencer o paciente do que é o melhor a ser feito conforme o conhecimento do médico e sua sabedoria, e no debate de questões bioéticas e biopolíticas, quando as formulações culturais entram em choque e os discursos são erigidos para resolução de problemas e tomadas de posições.

De forma muito significativa, as características aristotélicas do bom orador ${ }^{9}$ podem ser contrapostas aos critérios de erro médico que constam no Código de Ética Médica $^{10}$, revelando uma oposição clara entre Virtude e Imperícia, Sabedoria e Imprudência, e Benevolência e Negligência, e apontando para a necessidade de que um bom médico seja um bom orador.

\section{Dialética na Medicina}

A dialética se faz presente na pesquisa científica, pareando hipóteses e buscando a falsificação de uma delas para aceitação da segunda. Ocorre também em cada momento do raciocínio clínico, denominado hipotéticodedutivo, onde hipóteses são pareadas e atravessam um processo de reforço ou enfraquecimento conforme os dados coletados, sendo depuradas até um diagnóstico bem provável que será utilizado para planejamento terapêutico e para orientação do paciente ${ }^{11}$.

A dialética é a ferramenta básica do pensamento médico, confrontando diagnósticos, opções terapêuticas, regras gerais e situações específicas. É o ponto de tensão em que o médico busca suas conclusões.

\section{Lógica na Medicina}

A lógica está presente principalmente nas formulações acadêmicas e pedagógicas, em aulas expositivas e apresentações em congressos, onde uma sequência de raciocínios é colocada em ordem lógica para fins de transmissão de conhecimento. Ocorre também na consulta de pacientes de maior exigência, buscando uma explicação lógica e uma decisão baseada em informações mais precisas.

Auxilia o médico a validar com maior grau de certeza uma formulação dialética, buscando coerência discursiva interna e completando o raciocínio hipotético dedutivo. Sua forma básica consiste numa premissa maior, uma premissa menor e uma conclusão deduzida da conexão entre ambas.

\section{Discussão}

$\mathrm{O}$ ato médico inclui o encontro do médico e do paciente, sendo pautado na capacidade comunicativa de ambos, especialmente na do médico, para que possa ser concretizada uma atitude de benefício para o paciente. 
In these communication skills, essential to clinical practice, all the discourses are eventually used in different proportions and moments, Learning such skills is not an option for the dedicated physician, it is mandatory. The Brazilian Guidelines for Medical Education, for example, strongly recommends he teaching of such abilities $^{12}$.

To promote learning of communication skills, the practice and study of the four Aristotelian discourses as theorized by the Brazilian philosopher Olavo de Carvalho can be very useful tools, helping the medical school in planning pedagogical approaches and curricula to include the systematic learning of all discourses.

But how it can be used practically and how it could benefit the medical student?

The benefits of such studies include the: (1) development of empathic skills and attitudes, promoting a better understanding of the clinical situation; (2) selfdevelopment as individual and member of society; (3) increase of persuasion capability, used to the patient's best interests; (4) development of clinical, philosophical and scientific thought; and (5) the argumentative and deliberative improvement, favoring teamwork skills and ethical and bioethical reasoning.

To learn Poetics, medicine actually uses literature interpretation and narrative techniques within the health context $t^{13}$. Training in anamnesis and critical evaluation of the patients' story can be another important learning tool. Other forms to populate the imagination and increase empathy would be watching movies with bioethical dilemmas, reading autobiographical books of patients and physicians, and contemplating art with a critical point of view.

Rhetoric training can be made inside health policy debates, controversial questions in Bioethics, and other social themes that intertwine with medicine and health in general. But such debates need qualified methodology. Many bibliographical sources can be of inestimable help to the student of Medical Humanities. Rhetoric from Aristotle is widely regarded as one of the greatest books in the theme in the west civilization'. The New Rhetoric of Chaim Perelman ${ }^{14}$ and the book The Art of Being Right ${ }^{15}$ are other sources of interest, in which the student can find the valid and invalid forms of persuasion and argumentation.

Dialectic and Logic training are stimulated in the study of scientific papers, in the utilization of Evidence Based Medicine, in research projects and works throughout the graduate course, and in clinical discussions, exercising the hypothetical-deductive reasoning and explaining to others how some diagnostic or therapeutic plan was reached.

A careful reading of the Organon $^{16}$ is a very good start, as is the reading of many others works that address Logic and Dialectic ${ }^{17-18}$, making conscious all the pro-
Nessa capacidade comunicativa, todos os discursos são eventualmente utilizados, em diversas proporções e momentos, e a capacitação discursiva é um elemento fundamental na formação do médico, reconhecida até mesmo como elemento das Diretrizes Curriculares Nacionais para a graduação em medicina ${ }^{12}$.

A capacitação discursiva é coerente com o estudo e a prática dos quatro discursos na concepção aristotélica. Diversas ferramentas de treino podem ser utilizadas para auxiliar o docente e o discente no aprendizado dos quatro discursos. Os benefícios de tais estudos seriam: (1) a melhora da compreensão do paciente pelo médico por meio do desenvolvimento da capacidade empática, (2) o desenvolvimento como indivíduo e participante da sociedade, (3) o aprimoramento das capacidades discursivas de convencimento, (4) o aprimoramento das capacidades de raciocínio clínico, filosófico e científico e (5) o aumento da capacidade argumentativa e deliberativa, favorecendo o trabalho em equipa de forma ética. Para a capacitação poética, a medicina atualmente recorre à utilização da literatura e de técnicas de narração e interpretação dentro do contexto médico, como é o caso da Medicina Narrativa ${ }^{13}$. A realização de anamneses e sua correção crítica também pode ser uma ferramenta eficaz. Outras formas de aumentar a capacidade empática do acadêmico incluem filmes com discussão orientada, leitura de textos escritos por pacientes sobre sua experiência com a doença e com os médicos e contemplação orientada de obras artísticas.

O treino retórico pode ser feito ao participar de debates sobre políticas de saúde pública, questões controversas em bioética e demais assuntos da esfera pública. Mas os debates necessitam de crítica e metodologia. Fontes bibliográficas que podem colaborar para preparar o médico incluem não somente os livros básicos de bioética e saúde pública, mas principalmente a Retórica aristotélica ${ }^{9}$ o Tratado da Argumentação ${ }^{14}$ e o livro de Schopenhauer: Como Vencer um Debate sem Precisar Ter Razão ${ }^{15}$, onde o estudante aprenderá as formas válidas e inválidas de debate, estas tão necessárias no ambiente cultural brasileiro.

O treino dialético e o treino lógico são estimulados no estudo de artigos científicos, na utilização de medicina baseada em evidências, na iniciação científica durante a graduação e no levantamento de hipóteses e sua depuração durante o raciocínio clínico e a discussão de casos.

Uma leitura atenta do Organon aristotélico16 pode iniciar o estudo, assim como a leitura de diversas outras obras que tratam de lógica e dialética ${ }^{17-18}$, tornando consciente o processo de raciocínio clínico e científico e fornecendo ao estudante os conhecimentos metacogni- 
cess of clinical and scientific reasoning and developing metacognitive skills that could help the students in their rational capacity.

But the great discursive training lays in the practice of medicine itself, facing real patients with real problems and learning to think and to communicate at the side of an expert physician.

\section{Conclusions}

The physician is constantly influenced by the concrete situation narrated by his patient (Poetics), and constantly influences the patient himself. Rhetoric of good quality is essential to warrant patient adherence to treatment, which will be the result of a good and coherent clinical thought addressing causality nexus, interventions required and probable effects, or prognosis (Dialectic and Logic).

Finally, the good physician has to be skillful in the four discourses and able to transition between them within the clinical encounter, using them as an inherent aspect of his humanist education and practice.

\section{Acknowledgments}

*This article has been developed with a special grant for Scientific Research from FAPES (Research Development Foundation in Espírito Santo - Brazil) to Andreia Bosi (Medicine Graduation).

\section{Conflict of Interests}

The authors declare that there are no financial and personal relationships that could be viewed as a potential conflict of interests. tivos que poderão ajudá-lo a desenvolver a sua capacidade de reflexão.

Mas o grande treino discursivo encontra-se integralizado na prática médica, por exemplo, ao lidar com pacientes com problemas reais, aprendendo a refletir e a comunicar lado a lado com um médico mais experiente.

\section{Conclusão}

O médico é constantemente influenciado pela situação concreta de seu paciente e constantemente influencia o paciente. Retórica de boa qualidade é essencial para garantir aderência ao tratamento, o que será resultado de um raciocínio clínico coerente e de boa qualidade lidando com nexos causais, planos de tratamento e prováveis efeitos decorrentes, ou prognósticos.

Finalmente, o bom médico necessita de capacitação nos quatro discursos e de habilidade em transitar entre os mesmos no ambiente do encontro clínico, usando-os como aspecto inerente de sua prática e de sua educação humanística.

\section{Agradecimentos}

*Este artigo foi desenvolvido com fomento para Iniciação Científica da FAPES (Fundação de Amparo à Pesquisa do Espírito Santo) à Andreia Bosi (Acadêmica do Curso de Medicina).

\section{Conflito de Interesses}

Os autores declaram não existir qualquer relação de natureza financeira ou pessoal que possa, ser entendida como, ou representar, um potencial conflito de interesses. 


\section{References/ Referências}

1 - Zubiri X. Inteligência e Realidade. São Paulo: É Realizações, 2011.

2 - Pellegrino E. Philosophy of Medicine: Problematic and Potential. Journal of Medicine and Philosophy 1976; 1(1): 5-31.

3 - Giordano J. Foni Phronimos. An Interview with Edmund D. Pellegrino. Philosophy, Ethics and Humanities in Medicine 2010, vol. 5, p. 16.

4 - Marcum J. Humanizing Modern Medicine. An Introductory Philosophy of Medicine. Houston: Springer, 2008.

5 - Carvalho O. Uma Filosofia Aristotélica da Cultura: Introdução à Teoria dos Quatro Discursos. Rio de Janeiro: Topbooks, 1994.

6 - Illich I. Expropriação da Saúde: Nêmese da Medicina. Rio de Janeiro: Nova Fronteira, 1975.

7 -World Health Organization. Constitution of the World Health Organization.Disponível em: <http://www.who.int/governance/eb/ who constitution en.pdf>. Acesso em: 29 abr. 2014 .
8 - Gomes JB. Ética e Medicina: De Hipócrates à Criação dos Primeiros Hospitais. Rio de Janeiro: Revinter, 2012.

9 - Aristóteles. Retórica. São Paulo: Editora Martins Fontes, 2012.

10 - Conselho Federal de Medicina. Código de Ética Médica: Resolução CFM nº 1931/09. Brasília: Gráfica Teixeira, 2010.

11 - Réa-Neto A. Raciocínio clínico - o processo de decisão diagnóstica e terapêutica. Rev Ass Med Brasil 1998, 44(4): 301-11.

12 - Conselho Nacional de Educação. Diretrizes Nacionais Curriculares do Curso de Graduação em Medicina. Disponível em: <http:// portal.mec.gov.br/cne/arquivos/pdf/CES04. pdf>. Acesso em: 29 abr. 2014.

13 - Charon R. Narrative Medicine: Honoring the Stories of Illnesss. New York: Oxford University Press, 2006.
14 - Perelman C. Tratado da Argumentação: A Nova Retórica. São Paulo: Martins Fontes, 2005.

15 - Schopenhauer A. Como Vencer um Debate sem Precisar Ter Razão. São Paulo: Topbooks, 2003.

16 - Aristóteles. Órganon. São Paulo: Edipro, 2010.

17 - Santos MF. Lógica e Dialética: Lógica, dialética e decadialética. São Paulo: Paulus, 2007.

18 - Jospeh M. O Trivium: As Artes Liberais da Lógica, Gramática e Retórica. São Paulo: E Realizações, 2008. 